\title{
КОНЦЕПЦІЯ ПІДГОТОВКИ МАЙБУТНІХ МАГІСТРІВ ПСИХОЛОГІЇ ДО ПРОФЕСІЙНОЇ ДІЯЛЬНОСТІ В УМОВАХ НЕФОРМАЛЬНОЇ ОСВІТИ
}

У статті доведено, що перегляд окремих параметрів профресійної освіти майбутніх магістрів психології в контексті необхідності фрормування їхньої готовності до відповідальної та ефрективної конкурентної діяльності в умовах неформальної освіти потребує висвітлення цілісного авторського задуму в концептуальній формі.

На засадах пролонгованого емпіричного досвіду та за допомогою аналізу теоретичних позицій попередніх дослідників проблеми професійної освіти магістрів психології визначено специфіку профресійної діяльності майбутніх магістрів психології в умовах неформальної освіти; представлено педагогічну стратегію їхньої підготовки, визначено найбільш перспективні фрорми, методи та засоби педагогічного процесу.

Показано, що авторське розуміння специфіки профресійної діяльності майбутніх магістрів психології в умовах неформальної освіти грунтується на двох їі основних аспектах - фрунціях (просвітницька, коригувальна та розвивальна) та ролях (психолога і педагога), які має реалізовувати й виконувати фрахівець-психолог у зазначених умовах.

Доведено, що просвітницька функція може бути реалізована у вигляді індивідуальних занять, групових психологічних семінарів і програм в очній і в онлайн-фрормах.

Коригувальна та розвивальна функції забезпечує створення оптимальних умов для особистісного розвитку клієнтів, а головним видом психологічної підтримки обрано коучине.

Виділення ролі підприємия зумовлено недостатністю нормативних положень реалізації профресійної діяльності магістрів психології в умовах неформальної освіти, невизначеністю основних стратегій її організації та відсутністю гарантованого робочого місия.

Педагогічну стратегію підготовки представлено за фразами: проектування (спрямована на розроблення індивідуальних траєкторій розвитку всіх складників підготовки», технологізація (спрямована на ефрективну теоретичну і практичну підготовку) і коригування (спрямована на корекцію індивідуальної траєкторії підготовки майбутніх магістрів психології).

Реалізація визначеної педагогічної стратегії потребує адекватного вибору фрорм, методів і засобів навчання, до яких віднесено технологію змішаного навчання, інтерактивні технології, проектну технологію та польові (психологічні) практики.

Ключові слова: неформальна освіта, магістри психології, профресійна підготовка, концепція.

Постановка проблеми. Сучасне суспільство, зважаючи на проведені реформи, інтенсивний розвиток із часів незалежності, формує соціальний запит і актуалізує потребу в магістрах психології, здатних ефективно працювати в умовах неформальної освіти, яка значно відрізняється від формальної [1; 2].

Включене спостереження за особливостями функціонування психологів в умовах неформальної освіти в сучасному її варіанті дає змогу експлікувати такі важливі характеристики: доступність, комфортність, особистісно зорієнтований характер, логістичну та естетичну привабливість форм педагогічної та андрагогічної взаємодії. При цьому психологічні знання та практичні навички - один із найбільш популярних запитів, які дають змогу найбільш повної реалізації природніх потенцій кожній людині в реальності українського соціуму.
Мета статті - висвітлення авторської концепції підготовки майбутніх магістрів психології до професійної діяльності в умовах неформальної освіти.

Виклад основного матеріалу. Авторську концепцію підготовки майбутніх магістрів психології до професійної діяльності в умовах неформальної освіти представимо за такою логікою:

- визначення специфіки професійної діяльності майбутніх магістрів психології в умовах неформальної освіти;

- представлення педагогічної стратегії підготовки майбутніх магістрів психології до професійної діяльності в умовах неформальної освіти;

- визначення форм, методів і засобів, що забезпечать ефективну підготовку майбутніх магістрів психології до професійної діяльності в умовах трансорормації освіти. 
Авторське розуміння специфіки професійної діяльності майбутніх магістрів психології в умовах неформальної освіти ґрунтується на двох ії основних аспектах - фрункціях та ролях, які має реалізовувати й виконувати фахівець-психолог у зазначених умовах.

На нашу думку, основними функціями магістрів психології в умовах неформальної освіти є: освітня (просвітницька), коригувальна та розвивальна.

Так, освітня (просвітницька) фрункція магістрів психології передбачає підготовку, організацію та проведення просвітницької діяльності з проблем у сфері психології для різних верств населення. Ця фрункція діяльності психолога може бути реалізована у вигляді індивідуальних занять, групових психологічних семінарів й програм, які реалізуються і в очній і в онлайн-формах. Окремим напрямом реалізації освітньої функції є пропагандистська діяльність психолога, яка найчастіше пов'язана 3 діяльністю церков, політичних партій та об'єднань громадян. Проте можливі випадки, коли пропаганда підтримується урядом або місцевою владою, наприклад, пропаганда національних цінностей, здорового способу життя, енергозбереження тощо.

Коригувальна фрункція магістрів психології в умовах неформальної освіти незначно відрізняється від умов фрормальної освіти і передбачає психологічну допомогу дітям і дорослим, психотерапевтичну допомогу батькам, які мають дитину з вадами психологічного розвитку, коригування девіантної поведінки особистості, надання психологічної допомоги і захисту учасникам бойових дій та іншим громадянам, які опинилися в кризовій ситуації тощо. Ця функція вимагає отримання якнайповнішої інфрормації про клієнта, зокрема в ході спостереження та бесід з ним. Одним 3 ефективних способів коригування діяльності девіантної поведінки $є$ роз'яснення суті, значення і причин виникнення труднощів у клієнта, обговорення можливих варіантів їх подолання і схвалення за виправлені та усунені недоліки.

Розвивальна ффункція магістрів психології в умовах неформальної освіти забезпечує створення оптимальних умов для особистісного розвитку клієнтів. Ця галузь неформальної освіти в останні роки характеризується швидким зростанням та диверсифікацією освітніх послуг, адже висуває на перше місце освітньо-психологічні потреби окремої особистості з власним характером та світоглядом. Нині для громадян пропонується велика кількість різноманітних освітніх програм з особистісного розвитку, які стосуються хобі, дозвілля, музики, художнього мистецтва, спорту, вивчення іноземних мов тощо, що проводяться на базі культурних центрів, клубів, громадських організацій, бібліотек та позашкільних закладів.
Проте одним із найперспективніших видів психологічної підтримки вважаємо коучине, в якому магістр психології виконує для особистості роль персонального тренера.

Коучинг спрямований на досягнення особистістю конкретної мети в житті або професії. Він реалізується шляхом використання певних тренінгових технологій, що сприяють самоусвідомленню особистістю власних недоліків і слабких місць та визначенню конкретних кроків щодо їх усунення. Основним інструментом коучингу є постановка запитань, за допомогою яких коуч дає можливість особистості побачити ситуацію з іншої точки зору, а отже, сформувати оптимальну послідовність дій, які забезпечать вирішення цієї проблеми (Т. Осипова) [3].

Коучинг у неформальній освіті виконує низку завдань, що стосуються: забезпечення психолого-педагогічного супроводу особистісного розвитку громадян, забезпечення партнерської взаємодії між коучем та особистістю; зростання усвідомлення особистості про свої здібності та шляхи їх розвитку.

Означені функції знаходять своє відображення у двох традиційних для магістрів психології ролях - психолога і педагога та в одній інноваційній ролі - підприємия.

У цьому переліку роль психолога $є$ найбільш близькою і зрозумілою для магістрантів психології, адже спрямована на реалізацію коригувальної та розвивальної функцій в умовах неформальної освіти, що включені до освітньо-кваліфрікаційної характеристики фахівця цієї спеціальності.

Роль педагога пов'язана з реалізацією освітньої (просвітницької) функції магістра психології в умовах неформальної освіти і потребує окремої теоретичної підготовки, яка $€$ не дуже значною за обсягом і тривалістю.

Виділення ролі підприємця зумовлено тим, що професійна діяльність магістрів психології в умовах неформальної освіти характеризується недостатністю нормативних положень реалізації, невизначеністю основних стратегій її організації та відсутністю гарантій подальшої роботи, що актуалізує необхідність її самостійної організації, самостійного пошуку та залучення клієнтів до участі в тренінгах, навчальних семінарах, особистих консультаціях, аналізу та врахування їхніх потреб та побажань, самостійного розроблення освітньо-психологічних проектів, спрямованих на особистісний розвиток тощо. Ефективна реалізація магістрами психології цієї ролі в умовах нефооммальної освіти вимагає належної теоретичної та практичної підготовки, яка має розпочинатись із перших днів навчання та завершуватись останніми.

Педагогічну стратегію підготовки майбутніх магістрів психології до профресійної діяльності в умовах неформальної освіти представимо за 
такими фазами: проектування, технологізація і коригування.

Фаза проектування спрямована на розроблення індивідуальних траєкторій розвитку всіх складників підготовки магістрів психології, необхідних для забезпечення ефективності їхньої професійної діяльності в умовах неформальної освіти. При цьому індивідуальна траєкторія підготовки кожного магістра психології проектується на основі його поведінкових, внутрішньо-рефлексивних та інтелектуальних характеристик, ступеня його особистісної мотивації та встановленого початкового рівня готовності до професійної діяльності в умовах неформальної освіти.

Фаза технологізації спрямована на ефективну теоретичну і практичну підготовку майбутніх магістрів психології до професійної діяльності в умовах неформальної освіти. У межах теоретичної підготовки магістранти-психологи ознайомлюються 3 особливостями професійної діяльності в умовах неформальної освіти, її інструментами, перевагами й недоліками та «приміряють» на себе ролі педагога, психолога й підприємця. Продовженням теоретичної підготовки $є$ розроблення кожним магістром психології персонального «стартапу» для виходу на ринок неформальних освітніх послуг та його випробування в умовах польової (психологічної) практики.

Фаза коригування спрямована на коригування індивідуальної траєкторії підготовки майбутніх магістрів психології та розроблених ними персональних «стартапів», що ґрунтується на аналізі труднощів, з якими магістранти-психологи зустрілися на етапі реалізації індивідуальної траєкторії підготовки та випробування персональних «стартапів» у ході проходження педагогічної та польової (психологічної) практики.

Реалізація визначеної педагогічної стратегії підготовки майбутніх магістрів психології до професійної діяльності в умовах трансформації освіти потребує адекватного вибору форм, методів і засобів навчання, до яких нами зараховано технологію змішаного навчання, інтерактивні технології, проектну технологію та польові (психологічні) практики.

Так, технологія змішаного навчання та інтерактивні технології забезпечують повноцінну очну та дистанційну взаємодію всіх суб'єктів процесу підготовки майбутніх магістрів психології до професійної діяльності в умовах трансформації освіти засобами традиційного і електронного навчання. При цьому застосування технології змішаного навчання також забезпечить розвиток ІКТ-компетентності магістрантів-психологів, яка $€$ однією з ключових вимог інформаційного суспільства. А застосування інтерактивних технологій сприятиме розвитку критичного мислення й адекватної самооцінки майбутніх магістрів пси- хології, що відбувається в процесі аналізу труднощів, з якими вони зіткнулися у процесі теоретичної і практичної підготовки та випробування себе в нових ролях. Зазначені технології $€$ наскрізними для всього процесу підготовки майбутніх магістрів психології, адже відбивають усі особливості суб'єкт-суб'єктних відносин андрагогічного процесу навчання.

Вибір проектної технології зумовлений необхідністю розроблення кожним магістрантом-психологом власної індивідуальної траєкторії підготовки до професійної діяльності в умовах неформальної освіти, а також необхідністю розроблення ним персонального «стартапу» для виходу на ринок неформальних освітніх послуг, які $€$ ключовими концептами професійної підготовки.

Використання польових (психологічних) практик спрямоване на забезпечення для кожного магістранта-психолога можливості апробації розробленого персонального «стартапу» та випробування себе у нових ролях в умовах неформальної освіти - педагога, психолога та підприємця. Проходження польових (психологічних) практик дасть можливість магістранту-психологу впевнитись у правильному виборі професії, оцінити власні здобутки у навчанні, виявити власні слабкі місця, випробувати себе як фахівця неформальної освіти, а також перейняти досвід професіоналів цієї галузі.

Висновки і пропозиції. Авторська концепція підготовки майбутніх магістрів психології до професійної діяльності в умовах неформальної освіти базується на розумінні специфіки такої роботи та презентує педагогічну стратегію, послідовність підготовки, що закладає фундамент для побудови алгоритму майбутньої технології, змістовою основою якої стане використання оновленого змісту, форм та засобів педагогічного процесу.

Реалізація авторського задуму потребує включення певних інноваційних засобів навчання, окремих спецкурсів, тем і модулів освітньо-професійної програми підготовки магістрів психології.

\section{Список використаної літератури:}

1. Пономаренко О.В. Суперечності та складності неформальної освіти як платформи для професійної самореалізації фахівців із психології. Вісник Запорізького національного універсиmету: збірник наукових праць. Педагогічні науки ; головний редактор Г.В. Локарєва. Запоріжжя : Запорізький національний університет, 2018. № 2 (31). С. 45-50.

2. Пономаренко О.В. Важливі тенденції сучасної професійної освіти магістрів психології в контексті формування їхньої готовності до фахової діяльності в умовах неформальної освіти. Вісник Запорізького національного університету: збірник наукових праць. Педагогічні 
науки. Запоріжжя : Запорізький національний університет, 2019. № 1 (32). С. 86-91.

3. Осипова Т.Ю. Варіативність педагогічного наставництва в сучасному освітньому просторі. Науковий часопис НПУ імені М.П. Драгоманова. Серія 16 : Творча особистість учителя: проблеми теорії і практики. 2016. Вип. 28. С. 47-53.

Ponomarenko $\mathrm{O}$. Concept of preparation of future masters of psychology for professional activities in the conditions of informal education

The article proves that some parameters of professional education of future masters of psychology in the context of necessity to form their aptitude for responsible and effective competitive activity in the conditions of non-formal education require to be revised and presented, reflecting the author's vision in conceptual form.

The peculiarity of professional activity of future masters of psychology in the conditions of non-formal education is determined on the basis of prolonged empirical experience and analysis of theoretical statements of previous researchers of professional education of masters of psychology. The pedagogical strategy of their preparation is presented in the most advanced forms.

Corrective and developmental functions ensure the creation of optimal conditions for the personal development of clients, with coaching being the main type of psychological support.

Defining of the role as an entrepreneur is caused by insufficiency of normative provisions of realization of professional activity by masters of psychology in the conditions of non-formal education, uncertainty of the basic strategies of its organization and absence of a guaranteed workplace.

The pedagogical preparation strategy is presented in the following phases: design which is aimed at development of individual path of development of all components of preparation, technique of application, which is directed at effective theoretical and practical preparation. And finally, adjustment which is appointed at correction of the individual strategy of preparation of future masters of psychology.

The implementation of a particular pedagogical strategy requires an appropriate choice of forms, methods and teaching aids, which include blended learning technology, interactive technologies, project technology and field (psychological) study.

Key words: non-formal education, masters of psychology, vocational training, concept. 